\title{
A Stimulating Effect of Humic Compounds on The Growth of Legumes, Nodulation and Biological Nitrogen Fixation
}

\author{
Said Abbas Mohamed EL-Sayed ${ }^{1}$
}

\begin{abstract}
Humic substances have been reported to increase plant growth. A stimulating effect on the growth of legumes may improve biological nitrogen fixation in soils. The present investigation studied dry matter production, nodulation and $\mathbf{N}$ content in nodules of Pigeon peas [ Cajanus cajan (L.) Millsp. Variety Prabhat], Guar [Cyamopsis tetragonoloba (L.) Taub variety Santa cruz]. and Mungbean \{Vigna radiata (L.) Wilczek variety VC2419], grown in sand cultures containing a fertilizer mixture and 0 to $750 \mathrm{mg} \mathrm{Kg}^{-1}$ of fulvic acid (FA) or humic acid (HA). The results indicated that $\mathrm{FA}$ and $\mathrm{HA}$ were capable of stimulating dry matter production in the plants. Dry weights of roots and nodules showed a tendency to increase over the control at 75 to $350 \mathrm{mg} \mathrm{Kg}^{-1}$ of $\mathrm{FA}$ or HA. The increases in total dry matter production were statistically significant at $750 \mathrm{mg} \mathrm{Kg}^{-1}$ of $\mathrm{FA}$ or $\mathrm{HA}$, and a positive correlation was noticed between increases in dry weights of shoots, roots, and nodules and FA or HA concentrations. Fewer nodules were produced by plants receiving FA and HA treatments than the control, but the nodule mass was greater with FA and $\mathrm{HA}$ treatments. The $\mathrm{N}$ content of nodules was little affected by the treatments; although a tendency can be noticed that $75 \mathrm{mg} \mathrm{Kg}^{-1}$ of FA had decreased the $\mathbf{N}$ content in the nodules of both pigeon peas and Guar plants.
\end{abstract}

Key Words: Nitrogen fixation, legumes, fulvic acid, humus, soil organic matter.

\section{INTRODUCTION}

Humic substances have been reported to influence plant growth directly or indirectly. The indirect effects of humic compounds have been attributed to the improvement of soil physical, chemical, and biological conditions. directly, these compounds appeared to be capable of affecting plant growth through the acceleration of respiratory processes (Khristeva, 1968; Smidova, 1960; Averett et al., 1989; Xing and Chen, 1999), by increasing cell permeabilities (Gawronski, 1969; Ayuso et al., 1997; Malcolm, 1990), by hormonal growth responses (Vaughan, 1974; Azo and Yamaguchi, 1971; Poapst and Schnitzer, 1971; Cameron and, 1992; Davies et al., 1997), or by a combination of these processes. However most of these investigations were limited to study seed germination, shoot growth of young seedlings, and elongation of excised roots in vitro. Recently, evidence has been presented that humic compounds could also affect nutrient uptake (Dormaar, 1975, Levesque, 1970; Flaig and Sochtig, 1962; Concheri et al., 1996; Cook and Langford, 1998) and dry matter production of plants (Guminski et al., 1977; Lee and Bartlett, 1976; Cook et a/., 1996 Nardi et al., 1996 \& 2000).

Soil organic compounds, such as humus, may be beneficial to crop production. If the humic fraction is capable of increasing the growth of pigeon peas , guar, other legumes and improving biological $\mathrm{N}$ fixation, the latter may aid in the economical production of plant protein. Information on the role of humic compounds in the growth of legume crops is very limited.

The use of dilute sodium humate solutions has been reported to increase soybean yields(Varshney and Gaur, 1974; Muscolo et al., 1998). The use of various concentrations of humic compounds may shed some light as to the optimum levels required to induce beneficial growth effects (Stevenson, 1994; Hu et al., 2000). Therefore, the objectives of current study was to study dry matter production, nodulation- and $\mathrm{N}$ content of nodules in pigeon peas, guar and mungbean plants grown in sand cultures containing a fertilizer mixture and different levels of soil fulvic acid (FA) and humic acid (HA).

\section{MATERIALS AND METHODS}

\section{Experiment Layout:}

Fulvic and humic acids were extracted with $0.1 \mathrm{~N}$ $\mathrm{NaoH}$, from clay surface soil samples $(0-15 \mathrm{~cm})$ according to procedures as described previously (Tan, 1977, 1975; Page et al., 1982). The humic fractions obtained were freeze-dried and ground for further analysis. The purified humic fractions had an ash content of $<1.0 \%$, and elemental analysis revealed to very small concentrations of macronutrient and micronutrient elements (Tan, 1977; Page et al., 1982). Two grams of freeze dried FA were dissolved in $75 \mathrm{ml}$ of distilled water. After the $\mathrm{P}^{\mathrm{H}}$ was adjusted to 7.0, the volume was made up to $100 \mathrm{ml}$ with distilled water. This procedure yielded a FA solution containing $20000 \mathrm{mg} \mathrm{L}^{-}{ }^{1}$ of FA and was used as the stock solution in the greenhouse experiments I for the preparation of 0 to $750 \mathrm{mg} \mathrm{L}^{-1}$ of FA.

\footnotetext{
${ }^{1}$ Department of Soil and Water Science, Faculty of Agriculture, Al-Azhar University,Assiut, Egypt.

Received November 6, 2013, Accepted December 18, 2013
} 
Sand purchased locally was treated with concentrated $\mathrm{Hcl}$ and washed thoroughly with deionized water until CI free. It was then heated in an over for 48 $\mathrm{h}$ at $148^{\circ} \mathrm{C}$ to eliminate contamination with organisms. Block plastic pots (4L capacity) were sterilized with Clorox and washed with sterile water, after they were filled with $3 \mathrm{~L}(4.0 \mathrm{~kg})$ of sand and mixed with $3 \mathrm{~g}$ of a fertilizer mixture $\left(0 \% \mathrm{~N}-10 \% \mathrm{P}_{2} \mathrm{O}_{5}-20 \% \mathrm{k}_{2} \mathrm{O}\right)$ and $2 \mathrm{~g}$ of calcites limestone. These amounts of fertilizer and lime are equivalent to 706 and $471 \mathrm{~kg} / \mathrm{Fed}$, respectively. A $0,75,350$ or $750 \mathrm{mg} . \mathrm{L}^{-1}$ of FA were added to the mixture by pipetting the appropriate FA solutions per pot and mixing it with the sand. Based on $4 \mathrm{~kg}$ of sand per pot, $75 \mathrm{ppm}$ of $\mathrm{FA}$ required the addition of $15 \mathrm{ml}$ of FA stock solution, whereas 350 and $750 \mathrm{ppm}$ of FA required 70 and $150 \mathrm{ml} \mathrm{FA}$ solutions, respectively.

Five Pigeon peas [Cajanus cajan (L.) Millsp Var. Prabhat), five Guar [Cyamopsis tetragonoJoba (L.) Taub Var. Santa cruz) or ten Mungbean [Vigna radlata (L.) Wilczek var VC 2419) were seeded in the pots in May 2011.Each treatment was triplicated prior to planting, the seeds were inoculated with Okadin, a commercial inoculants, at the rate suggested by the manufacturer. The experimental design was a completely randomized design (Snedecor and Cochran, 1981; SAS, 1985) in the greenhouse and rotated at 5 days intervals. Watering was done every day as needed with deionizer water to approximately field capacity. Field capacity was approximately by observing the amount of water held by the sand medium against gravity, after which the pots were watered to a predetermined weight. With mungbean, the plant population per pot was thinned after germination to 5 plants. The plants were allowed to grow for 40 days, after they were harvested and separated into shoots (leaf and stem), roots, and nodules. The number of nodules was counted. Because the nodules and roots of the mungbean plants were so small, no nodule counts were made, and the mungbean roots and nodules were combined together for further analysis. The various plants parts were rinsed thoroughly with deionized water and dried overnight at $75^{\circ} \mathrm{C}$ in a forced - draft oven for dry matter weight determination. The nodules of Pigeon peas and guar plants were then ground and analyzed for total $\mathrm{N}$ content by the micro -Kjeldahl method (Jackson, 1960; Page et al., 1982).

The greenhouse experiments were repeated in May 2012 with HA. The HA was prepared and added to sand in similar fashion, as was FA in the summer before.

\section{Statistical analysis:}

The data obtained were analyzed for significance by analysis of variance. And the least significant difference
$\left(\mathrm{LSD}_{0_{01}}\right)$ was calculated at the $90 \%$ confidence level. In addition - linear regression analysis were performed (Snedecor and Cochran. 1981; SAS, 1985).

\section{RESULTS and Discussion}

\section{Dry Matter Production:}

The weight of dry matter roots and nodules of 40 days old pigeon peas plants showed a tendency to increase over that of the control by treatments with 75 to $350 \mathrm{mg} \mathrm{kg}-{ }^{1}$ of FA (Table 1). Dry weights of roots and nodules of pigeon peas plants were significantly increased at $75 \mathrm{mg} \cdot \mathrm{kg}^{-1}$ FA concentration. But, dry weights of shoots were significantly decreased (Table 1). These results were coincided with the results of Davies et al., (1997); Nardi et al., (1996 \& 2000). The differences in results between 0 to $750 \mathrm{mg} \mathrm{kg-}{ }^{1}$ of FA were not significant by analysis of variance for dry weight of shoots but were significant at $750 \mathrm{mg} \mathrm{kg}^{1}$ of FA for dry weights of roots and nodules. The experiments with HA yielded supporting evidence for the observations with FA. Statistically the differences were not significant for shoots but were significant at 350 and $750 \mathrm{mg} \mathrm{kg}^{-}{ }^{1}$ of HA for roots and nodules (Averett et al., 1989; Stevenson, 1994; Ayuso et al., 1997; Hu et al, 2000).

Regression analysis revealed a linear regression between shoot, root, and nodule dry weights and FA and HA treatments (Fig.1). The data showed a good fit, and the values of the correlation coefficients(r) were indicative of significance at the 99 to $95 \%$ level of probability.

The dry matter in shoots and roots of guar plants (Table2) exhibited a similar increasing trend as that discussed for pigeon peas. The effect of increasing concentrations of FA to increase dry matter content over the control was still demonstrated, although individual comparisons of data at 0,75 , and $350 \mathrm{mg} \mathrm{kg}^{-1}$ of FA revealed differences that were statistically non significant. At $750 \mathrm{mg} \mathrm{kg}^{-1}$ of $\mathrm{FA}$, the increase in dry weight of shoots and roots was significant at the $90 \%$ confidence level. Dry weight of guar nodules was not affected by FA. The results with HA were less obvious, but the tendency of an increase in dry weight of roots was still noticed (Cameron and Sohn, 1992; Muscolo et al., 1998).

The effect of FA and HA on dry matter production of mungbean plants are presented in Table 3. The data from the FA experiments showed that dry weight of shoots, roots, and nodules increased progressively as the FA treatments increased from 0 to $750 \mathrm{mg} \mathrm{kg}^{-1}$. These increases were statistically significant at $750 \mathrm{mg}$ $\mathrm{kg}^{-1}$ of FA or HA (Cook and Langford, 1998; Concheri et al., 1996). 
Table 1. Dry matter weights of shoots, roots, and nodules (gm per pot per 5 plants) of pigeon peas plants (40 days) as affected by various FA and HA concentrations*

\begin{tabular}{|c|c|c|c|c|}
\hline Treatment (mg kg- $\left.{ }^{1}\right)$ & Shoots & Roots & Nodules & Total \\
\hline $0 \mathrm{FA}$ & 2.841 & 0.803 & 0.112 & 3.756 \\
\hline $75 \mathrm{FA}$ & 2.655 & 0.880 & 0.118 & 3.653 \\
\hline $350 \mathrm{FA}$ & 3.126 & 0.971 & 0.129 & 4.226 \\
\hline $750 \mathrm{FA}$ & 3.188 & 1.064 & 0.146 & 4.398 \\
\hline $\mathrm{LSD}_{0.01}$ & 0.485 & 0.190 & 0.024 & ---- \\
\hline \multicolumn{5}{|c|}{ Regression Coefficient ,r** } \\
\hline Shoots & $y=2.77+0.0006 x$ & & $\mathrm{r}=0.849 *$ & \\
\hline Roots & $y=0.829+0.0004 x$ & & $\mathrm{r}=0.980^{* *}$ & \\
\hline Nodules & $\mathrm{y}=0.113+0.00005 \mathrm{x}$ & & $\mathrm{r}=0.999 * *$ & \\
\hline Total & $\mathrm{y}=3.712+0.00105 \mathrm{x}$ & & $r=0.936 * *$ & \\
\hline $0 \mathrm{HA}$ & 2.836 & 0.807 & 0.112 & 3.755 \\
\hline $75 \mathrm{HA}$ & 2.987 & 0.897 & 0.136 & 4.020 \\
\hline $350 \mathrm{HA}$ & 3.021 & 1.108 & 0.151 & 4.280 \\
\hline $750 \mathrm{HA}$ & 3.131 & 0.984 & 0.141 & 4.256 \\
\hline $\mathrm{LSD}_{0.01}$ & 0.696 & 0.133 & 0.023 & $-\cdots$ \\
\hline \multicolumn{5}{|c|}{ Regression Coefficient,r** } \\
\hline Shoots & $y=2.90+0.0004 x$ & & $\mathrm{r}=0.915^{* *}$ & \\
\hline Roots & $y=0.877+0.0003 x$ & & $r=0.626$ & \\
\hline Nodules & $y=0.126+0.00004 x$ & & $r=6.34$ & \\
\hline Total & $\mathrm{y}=3.903+0.00074 \mathrm{x}$ & & $r=0.825^{*}$ & \\
\hline
\end{tabular}

**** Significant at the 0.05 and 0.01 levels, respectively.

+ LSD $_{0.01}=$ Least significant difference at the $90 \%$ confidence level.

++ Accordin9 to Snedecor and Cochran (1981) and SAS (1985), $r$ stands for correlation coefficient, whereas theregression coefficient refers to the slope of the regression curve or the $b$ units in $Y=a+b x$. Review process insisted that use regression coefficient for $r$.

Table 2. Dry matter weights of shoots, roots, and nodules (gm per pot per 5 plants) of guar plants (40 days) as affected by various FA and HA concentrations*

\begin{tabular}{|c|c|c|c|c|}
\hline Treatment (mg kg- $\left.{ }^{\mathrm{I}}\right)$ & Shoots & Roots & Nodules & Total \\
\hline $0 \mathrm{FA}$ & 3.329 & 1.997 & 0.081 & 5.407 \\
\hline $75 \mathrm{FA}$ & 3.370 & 2.087 & 0.061 & 5.518 \\
\hline $350 \mathrm{FA}$ & 3.460 & 2.054 & 0.074 & 5.588 \\
\hline $750 \mathrm{FA}$ & 4.079 & 2.827 & 0.077 & 6.983 \\
\hline $\mathrm{LSD}_{0.01}$ & 0.562 & 0.336 & 0.028 & --- \\
\hline \multicolumn{5}{|l|}{ Regression Coefficient , $\mathrm{r}^{* *}$} \\
\hline Shoots & \multicolumn{2}{|c|}{$y=3.27+0.0010 x$} & $\mathrm{r}=0.945^{* *}$ & \\
\hline Roots & \multicolumn{2}{|c|}{$\mathrm{y}=1.93+0.0011 \mathrm{x}$} & $\mathrm{r}=0.895^{*}$ & \\
\hline Nodules & \multicolumn{2}{|c|}{$\mathrm{y}=0.072+0.00006 \mathrm{x}$} & $\mathrm{r}=0.221$ & \\
\hline Total & \multicolumn{2}{|c|}{$\mathrm{y}=5.272+0.00216 \mathrm{x}$} & $\mathrm{r}=0.921 * *$ & \\
\hline $0 \mathrm{HA}$ & 3.822 & 2.010 & 0.080 & 5.912 \\
\hline $75 \mathrm{HA}$ & 3.925 & 2.101 & 0.057 & 6.083 \\
\hline $350 \mathrm{HA}$ & 4.3032 & 2.196 & 0.079 & 6.5782 \\
\hline $750 \mathrm{HA}$ & 4.025 & 2.348 & 0.088 & 6.461 \\
\hline $\mathrm{LSD}_{0.01}$ & 0.842 & 0.320 & 0.019 & --- \\
\hline \multicolumn{5}{|l|}{ Regression Coefficient ,r** } \\
\hline Shoots & \multicolumn{2}{|c|}{$y=3.87+0.0003 x$} & $\mathrm{r}=0.835^{*}$ & \\
\hline Roots & \multirow{2}{*}{\multicolumn{2}{|c|}{$\begin{array}{l}y=2.04+0.0005 x \\
y=0.068+0.00003 x\end{array}$}} & $\mathrm{r}=0.990 * *$ & \\
\hline Nodules & & & $r=0.622$ & \\
\hline Total & \multicolumn{2}{|c|}{$y=5.978+0.00083 x$} & $\mathrm{r}=0.808^{*}$ & \\
\hline
\end{tabular}

*** Significant at the 0.05 and 0.01 levels, respectively.

$+\mathrm{LSD}_{0.01}=$ Least significant difference at the $90 \%$ confidence level.

++ According to Snedecor and Cochran (1981) and SAS (1985), $r$ stands for correlation coefficient, whereas the regression coefficient refers to the slope of the regression curve or the $b$ units in $\mathrm{Y}=a+b x$. Review process insisted that use regression coefficient for $r$. 
Table 3. Dry matter weights of shoots, roots, and nodules (gm per pot per 5 plants) of mungbean plants (40 days) as affected by various FA and HA concentrations* .

\begin{tabular}{|c|c|c|c|}
\hline Treatment $\left(\mathrm{mg} \mathrm{kg}^{1}{ }^{1}\right)$ & Shoots & Roots+ Nodules & Total \\
\hline $0 \mathrm{FA}$ & 1.210 & 0.440 & 1.650 \\
\hline $75 \mathrm{FA}$ & 1.439 & 0.527 & 1.966 \\
\hline $350 \mathrm{FA}$ & 1.604 & 0.593 & 2.197 \\
\hline $750 \mathrm{FA}$ & 1.634 & 0.864 & 2.498 \\
\hline $\mathrm{LSD}_{0 \cdot 01}$ & 0.351 & 0.182 & $\ldots-$ \\
\hline \multicolumn{4}{|c|}{ Regression Coefficient, $\mathrm{r}^{* *}$} \\
\hline Shoots & $\mathrm{Y}=1.33+0.0006 \mathrm{x}$ & $\mathrm{r}=0.857^{*}$ & \\
\hline Roots+Nodules & $Y=0.444+0.0006 x$ & $\mathrm{r}=0.980 * *$ & \\
\hline Total & $\mathrm{Y}=1.774+0.0012 \mathrm{x}$ & $\mathrm{r}=0.964 * *$ & \\
\hline $0 \mathrm{HA}$ & 1.207 & 0.434 & 1.641 \\
\hline $75 \mathrm{HA}$ & 1.443 & 0.458 & 1.901 \\
\hline $350 \mathrm{HA}$ & 1.558 & 0.454 & 2.012 \\
\hline $750 \mathrm{HA}$ & 1.619 & 0.515 & 2.134 \\
\hline $\mathrm{LSD}_{0.01}$ & 0.341 & 0.051 & $\ldots .$. \\
\hline \multicolumn{4}{|c|}{ Regression Coefficient, $\mathrm{r} * *$} \\
\hline Shoots & $Y=1.32+0.0005 x$ & $\mathrm{r}=0.863^{*}$ & \\
\hline Roots+Nodules & $Y=0.436+0.00010 x$ & $\mathrm{r}=0.923 * *$ & \\
\hline Total & $\mathrm{Y}=1.756+0.0006 \mathrm{x}$ & $\mathrm{r}=0.899 *$ & \\
\hline
\end{tabular}

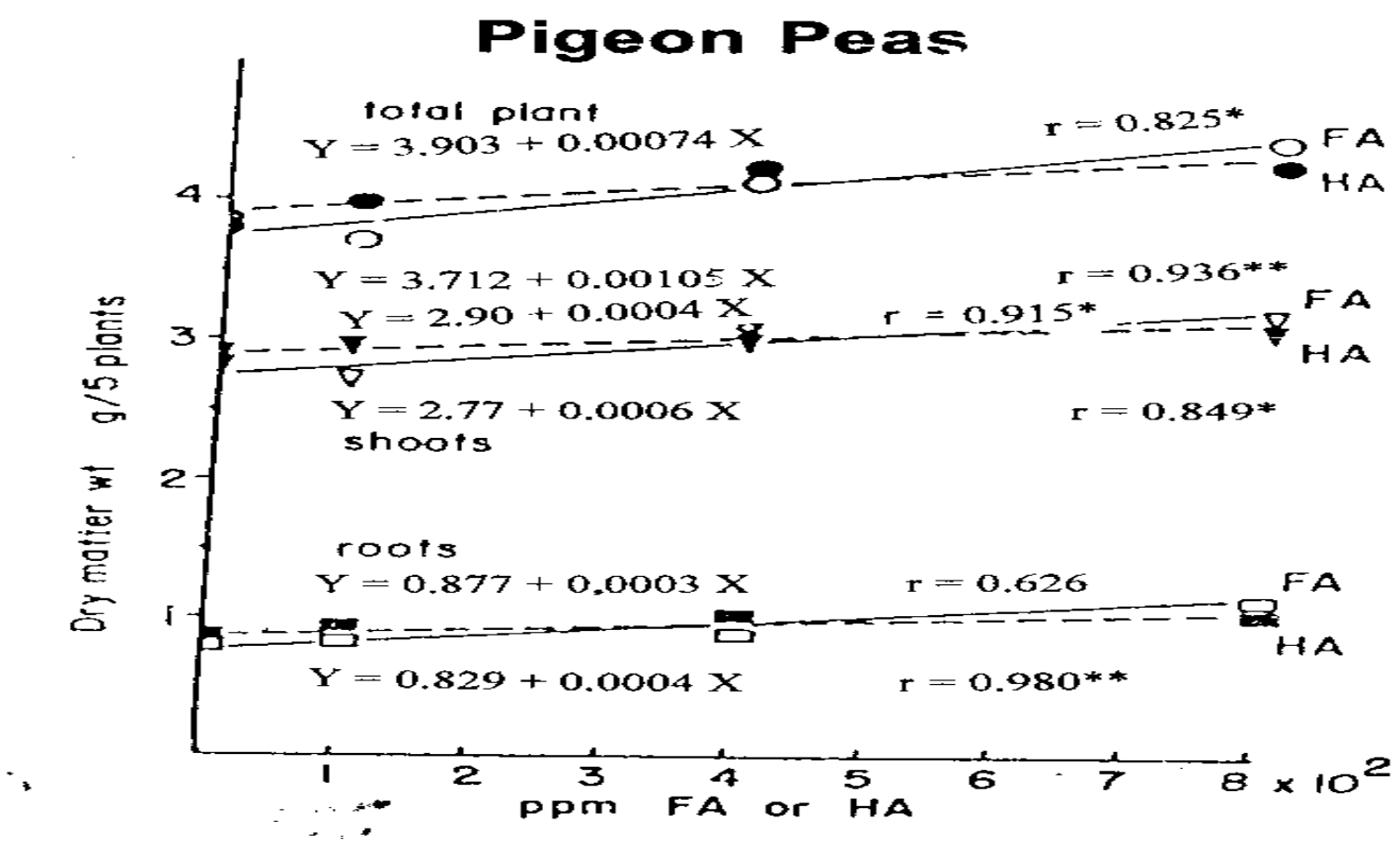

Fig. 1. Relationship between the increase in dry matter production of pigeon peas plant and FA and HA treatments, Regression coefficients ( $r$ ) show correlations significant at the 95\% (*), and 99\%(**) levels of probability. 


\section{Nodulation and Percent of Nitrogen in Nodules:}

Fewer nodules were formed as a results of treatments with FA and HA. (Tables 4 and 5). The decrease in nodulation was noticeable at $750 \mathrm{mg} \mathrm{kg}^{-1}$ of FA and HA. However, when nodule dry weights were studied , it appeared that nodule weight increased in Pigeon peas plants (Table 4) as the applied concentrations of FA and $\mathrm{HA}$ increased from 0 to $750 \mathrm{mg} \mathrm{kg}^{-1}$. The latter result was supported by results with guar plants at 350 and 750 $\mathrm{mg} \mathrm{kg}^{-1}$ of FA or HA (Table 5).

The $\mathrm{N}$ content of the nodules, as affected by FA or HA treatments, was inconsistent (Xing and Chen, 1999 and EL-Sayed 2002). Although a tendency to decrease in $\mathrm{N}$ content was noted in Pigeon peas nodules as a result of FA treatments, the data at 350 and $750 \mathrm{mg} \mathrm{kg}^{-1}$ of HA were nonsignificantly different from the control (Table 4). Lack of definite trend in $\mathrm{N}$ content of guar nodules was also observed as a result of treatment with FA (Table 5). However, application of HA seemed to increase somewhat the $\mathrm{N}$ content of guar nodules, with $75 \mathrm{mg} \mathrm{kg}^{-1}$ of HA yielding the highest levels (Cook et al., 1996; Malcolm. 1990; EL-Khtatib et al ., 2013).

\section{CONCLUSIONS}

It can be concluded that the soil humic fraction contribute to a better growth of legume plants by stimulating total dry matter production. Both FA and HA were capable of increasing the total amount of dry weight in pigeon peas, guar, and mungbean plants. In general, shoot, root, and nodule dry weights showed a tendency to increase by treatment of the plants with 75 to $350 \mathrm{mg} \mathrm{kg}^{-1}$ of FA and HA.

Fewer nodules were produced from pigeon peas and guar plants receiving FA and HA than for the control plants, but the nodules had greater mass. Although some variations were noted in $\mathrm{N}$ content of these nodules. A small percent of $\mathrm{N}$ in nodules in case of FA and HA treated compared to control.

Table 4. Effect of FA and HA concentrations on number, weights, and $\mathrm{N}$ content of nodules of pigeon peas plants *

\begin{tabular}{|c|c|c|c|}
\hline $\begin{array}{c}\begin{array}{c}\text { Treatment } \\
\left(\mathrm{mg} \mathrm{kg}^{1}\right)\end{array} \\
\end{array}$ & $\begin{array}{c}\text { No. of nodules/5 } \\
\text { Plants } \\
\end{array}$ & $\begin{array}{c}\text { Weight/5 } \\
\text { Nodules, (mg) } \\
\end{array}$ & $\%$ of $\mathrm{N}$ \\
\hline${ }_{0} \mathrm{FA}$ & 109 & 11.7 & 5.51 \\
\hline $75 \mathrm{FA}$ & 84 & 15.2 & 4.42 \\
\hline $350 \mathrm{FA}$ & 88 & 15.8 & 4.96 \\
\hline $750 \mathrm{FA}$ & 66 & 23.4 & 5.16 \\
\hline $\mathrm{LSD}_{\text {o.o1 }}$ & 9.8 & 2.01 & 0.79 \\
\hline \multicolumn{4}{|c|}{ Regression Coefficient ,r** } \\
\hline Number of nodules & $Y=99.6-0.043 x$ & $\mathrm{r}=-0.861^{*}$ & \\
\hline Nodule weight & $\mathrm{Y}=12.3+0.014 \mathrm{x}$ & $\mathrm{r}=0.957 * *$ & \\
\hline$\%$ of $\mathrm{N}$ & 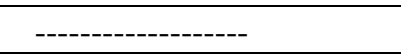 & $\mathrm{r}=0.077$ & \\
\hline $0 \mathrm{HA}$ & 111 & 11.2 & 5.16 \\
\hline $75 \mathrm{HA}$ & 84 & 17.4 & 4.96 \\
\hline $350 \mathrm{HA}$ & 87 & 18.5 & 5.09 \\
\hline $750 \mathrm{HA}$ & 79 & 19.1 & 5.10 \\
\hline $\mathrm{LSD}_{0 \cdot 01}$ & 15.3 & 2.7 & 0.46 \\
\hline \multicolumn{4}{|c|}{ Regression Coefficient ,r** } \\
\hline Number of nodules & $Y=98.5-0.004 x$ & $r=-0.713$ & \\
\hline Nodule weight & $Y=14.1+0.008 x$ & $\mathrm{r}=0.742$ & \\
\hline$\%$ of $\mathrm{N}$ & 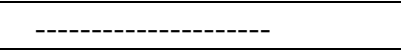 & $\mathrm{r}=0.124$ & \\
\hline
\end{tabular}


Table 5. Effect of $F A$ and $H A$ concentrations on number, weights, and $N$ content of nodules of guar plants*.

\begin{tabular}{|c|c|c|c|}
\hline $\begin{array}{c}\text { Treatment } \\
\text { mg kg- }^{1}\end{array}$ & \begin{tabular}{|c|}
$\begin{array}{c}\text { No. of nodules/5 } \\
\text { Plants }\end{array}$ \\
\end{tabular} & $\begin{array}{c}\text { Weight } / 5 \\
\text { Nodules, (mg) }\end{array}$ & $\%$ of $N$ \\
\hline $0 \mathrm{FA}$ & 70 & 12.7 & 5.51 \\
\hline $75 \mathrm{FA}$ & 50 & 12.7 & 4.42 \\
\hline $350 \mathrm{FA}$ & 40 & 19.8 & 5.12 \\
\hline $750 \mathrm{FA}$ & 22 & 37.4 & 5.64 \\
\hline $\mathrm{LSD}_{0.01}$ & 9.1 & 2.2 & 0.43 \\
\hline \multicolumn{4}{|c|}{ Regression Coefficient, $\mathrm{r}^{* *}$. } \\
\hline Number of nodules & $y=62.8-0.06 x$ & $\mathrm{r}=-0.953^{* *}$ & \\
\hline Nodule weight & $y=10.23+0.033 x$ & $\mathrm{r}=0.976^{* *}$ & \\
\hline$\%$ of $\mathrm{N}$ & 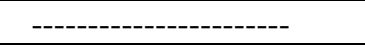 & $\mathrm{r}=0.471$ & \\
\hline${ }_{0} \mathrm{HA}$ & 82 & 10.8 & 4.17 \\
\hline $75 \mathrm{HA}$ & 88 & 7.5 & 5.76 \\
\hline $350 \mathrm{HA}$ & 70 & 12.4 & 5.11 \\
\hline $750 \mathrm{HA}$ & 58 & 16.4 & 5.64 \\
\hline $\mathrm{LSD}_{0 \cdot 01}$ & 7.8 & 1.97 & 0.55 \\
\hline \multicolumn{4}{|c|}{ Regression Coefficient, $\mathrm{r}^{* *}$} \\
\hline Number of nodules & $\mathrm{y}=86.0-0.05 \mathrm{x}$ & $\mathrm{r}=-0.952^{* *}$ & \\
\hline Nodule weight & $Y=8.73+0.010 x$ & $r=0.885^{*}$ & \\
\hline$\%$ of $\mathrm{N}$ & 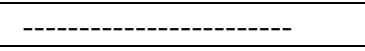 & $\mathrm{r}=0.527$ & \\
\hline
\end{tabular}

*,** Significant at the 0.05 and 0.01 levels, respectively.

$+\mathrm{LSD}_{0} \cdot 01=$ Least significant difference at the $90 \%$ confidence level.

++ According to Snedecor and Cochran (1981) and SAS (1985), $r$ stands for correlation coefficient, whereas the regression coefficient refers to the slope of the regression curve or the $b$ units in $\mathrm{Y}=a+b x$. Review process insisted that use regression coefficient for $r$.

\section{REFERENCES}

Averett, R.C.; J. A. Leenheer; D. M. Mcknigh and K.A. Thorn (ed.) 1989. Humic substances in the Suwannee River, Georgia: Interactions, properties and proposed structures U.S. Geol. Survey Open File. Rep. 87-557.

Ayuso, M; J.L. Moreno; T. Hernandez and C. Garcia. 1997. Characterization and evaluation of humic acids extracted from urban waste as liquid fertilizers. J. Sci. Food Agric. 75:481-488

Azo, S and T. Yamaguchi. 1971. Physiological effect of humic acid. Promotive action of nitrohumic acid on elongation and physiological activity of crop plant root. Nippon Dojo Hiryogaku

Zasshi. 42: 291-294.

Cameron, D. F and M.L.Sohn. 1992. Functional group content of soil and sedimentary humic acids determined by CP/MAS $13_{\mathrm{CNMR}}$ related to conditional $\mathrm{Zn}^{2+}$ and $\mathrm{Cd}^{2+}$ formation constants. Sci. Total Environ. 113:121-132.

Concheri, G; S. Nardi; F. Reniero and G. Dell' Agnola. 1996. Structural characteristics and biological activities of humic substances within the Ah horizon (Calcic luvisol). Plant Soil. 179:65-72.

Cook, RL; C.H. Langford; R Yamdagni and C.M Preston. 1996. A modified cross-polarization magic angle spinning ${ }^{13} \mathrm{C}$ NMR procedure for the study of humic materials Anal. Chem. 68: 3979-3986.
Cook, RL. And C.H. Langford. 1998. Structural characterization of a fulvic acid and a humic acid using solid-state ramp-Cp-MAS ${ }^{13} \mathrm{C}$ nuclear magnetic resonance. Environ. Sci. Technol 32. 719-725.

Davies, G; A. Fataftah; A. Cherkasskiy; E.A. Ghabbour; A.

Radwan; M. Balasubramanian, J. Budnick and B. xing. 1997. Tight metal binding by humic acids and its role in biomineralization J. Chem. Joe., Dalton Trans. 40474060 .

Dormaar, J. F. 1975. Effects of humic substances from chernozemic Ah horizons on nutrient uptake by Phaseolus Vulgaris, and Festuca ascabrella. Can. J. Soil Sci. 55:111-118.

EL-Khatib, H.A; S.M. Gaber and S.H. Brengi. 2013. Impact of Humic acid amendments on alleviation the harmful effects of cadmium in radish and bean plants. Alex. Sci. Exch. Jour .34(2):263-282.

EL-Sayed, S.A.M. 2002. Chemical composition of fulvic acids exteacted from sewage sludge-soli mixtures. The First Conf. Of the Central Agric. Pesticide Lab., 3-5 Sep., 2002 Pp 231-245.

Flaig. W and H. Sochtig. 1962. Einfluss organischer Stoffe auf die Aufnahme anorganischer lonen. Agrochimica 6:251-264. 
Gawronski, E. 1969. The influence of humic acid on germination of photosensitive lettuce seeds: IV. Comparison of a physiological activity of humic acid preparations of different origin with their chemical composition Ann. Univ. Mariae Curie. Sklodowska Sect. C: $24: 241-436$.

Guminski, S; D. Augustyn and J. Sulej. 1977. Comparison of some chemical and physico-chemical properties of natural and model sodium humates and of the biological activity of both substances in tomato water cultures. Acta Soc. Bot. Pol. 46:437-448.

Hu, W.G; J.D. Mao; B. Xing and K. Schmidt - Rohr. 2000. Poly (methylene) crystallites in humic substances detected by nuclear magnetic resonance Environ. Sci. Technol 34:530-534.

Jackson, M.L. 1960. Soil chemical analysis. Prentice Hall, Inc., Englewood Cliffs, N.J.

Khristeva, L.A. 1968. About the nature of physiologically active substances of the soil humus and or organic fertilizers and their agricultural importance. P. 701-721. In F.V. Hernando (ed.) Pontificia academic scientarium citta del Vatican. John Wiley \& Sons Inc., New York.

Lee, Y.S and R.J. Bartlett. 1976. Stimulation of plant growth by humic substances. Soil Scl. Soc. Am. J. 40:876-879.

Levesque, M. 1970. Contribution de I'acide fulvique et des complexes fulvo-metafliques a la nutrition mineral des plants. Can. J. Soil. Sci. 50:385-395.

Malcolm, R.L. 1990. The uniqueness of humic substances in each of soil, stream and marine environments. Anal. Chim. Acta. 232: 19-23.

Muscolo, A; S. Cutrupi and S. Nardi. 1998. IAA detection in humic substances. Soil BioI. Biochem. 30 (8/9): 11991201.

Nardi, S; G. Concheri and G. Dell' Agnola. 1996 Biological, activity of humus. P. 361-406. In A. Piccolo (ed.) Humic substances in terrestrial ecosystems Elsevier, Amsterdam.
Nardi, S; D. Pizzeghello; F. Reniero and N. Rascio 2000. Chemical and biochemical properties of humic substances isolated from forest soils and plant growth. Soil Sci Soc. Am. J. 64: 639-645.

Page, A.L; R.H. Miller and D.R. Keeney. 1982. Methods of soil analysis part 2: chemical and Microbiological properties. Amer. Soc. Agron., Madison, Wisconsin, USA.

Poapst. P. A and M.Schnitzer 1971. Fulvic acid and adventitious root formation. Soil BioI. Biochem. 3: 215219

SAS (Statistical Analysis System) 1985. SAS User's guide version 5. Cary, North Carolina: SAS Institute, USA.

Smidova, M. 1960. The influence of humus acid on the respiration of plant roots. Biol. Plant. 2: 152-164.

Snedecor, G. W. and W.G. Cochran 1981. Statistical Methods 7th Iowa State Univ. Press Ames, Iowa, USA. Stevenson, F.J. 1994.Humus Chemistry: Genesis Composition, reactions, $2^{\text {nd }}$ ed. John Wiley \& Sons, New York.

Tan, K.H. 1975. Infrared absorption similarities between hymatomelanic acid and methylated humic acid. Soil. Sci Soc. Am. Proc. 39: 70-73.

Tan, K.H. 1977. Infrared spectra of humic and fulvic acids containings silica, metal ions and hygroscopic moisture. Soil Sei. 123: 235-240.

Varshney, T.N. and A.C. Guar 1974. Effect of spraying sodium humate and hydroquinone on Glycine max var. Bragg and Solanum Iycopersicum var. Heiz. 1370. Curr Sci. 43: 95-96.

Vaughan, D. 1974. A Possible mechanism for humic acid action on cell elongation in root segments of Pisum sativum under aseptic condition. Soil Biol. Biochem. 6: 241-247.

Xing, B and Z Chen. 1999. Spectroscopic vidence for condensed domains in soil organic matter. Soil. Sci. 164:40-47. 


\section{الملخص العربي}

\section{التأثير المنشط للمركبات الدبالية على النمو وتكوين العقد البكتيرية والتثبيت الحيوى للنيتروجين في}

\section{البقوليات}

$$
\text { سعيد عباس مُمّمّ السيد }
$$

الزيادة الكليـة في المـادة الجافـة النابجـة كانـت معنويـة عنــ تركيـز

(750) جـزء في المليـون لكـل مسن حمض الفلفيـك (FA)؛ وحمـض كـ (FA)

الميوميك(HA) حيث لوحظ وجود تلازم موجب بين الزيادة فن الوزن

الجاف لكل من السيقان والجذور والعقد البكتيرية وتركيز كل من حض

الفلفيك (FA)؛ وحمض الفيوميك (HA).

لوحظ وجـود قليـل مـن العقـد البكتيريـة بالنبـاتات المضـاف اليها

حمض الفلفيك (FA)؛ ومضض الميوميك(HA) وان حجم هذه العقد البكتيرية كان كبيرا بالمقارنه بالكنترول.

محتـوى النيتروجــين في العقــد البكتيريسة كــان قلـيلا عنـــ تركيـز

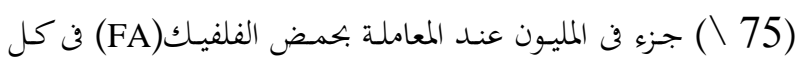

من نباتات بسلة الطيور والجوار.
تعمل المواد الدباليهه على زيادة نمو النبـاتات؛ وذات تأثير منشط

لنمو البقوليات حيـث تعمل على تحسين التثبيت الحيـوى للنيتروجين بالتربه.

تم دراسة الوزن الجاف وتكوين العقد البكتيرية والمحتوى النيتروجينى بالعقد في كل من بسلة الطيور والجوار وفول المانج حيث تم نموهم في بيئة رملية تحتوى على خليط من اسمدة حض الهيوميك (HA) وحض بـ الفلفيك (FA) واشارت النتائج الى ان كل من حض الهيوميك (HA) وحمض الفلفيـك (FA) ادت المى زيادة انتاج المـادة الجافـة في النبـاتات وكذلك الوزن الجاف لكل من الجذور والعقد البكتيرية حيث اظهرت

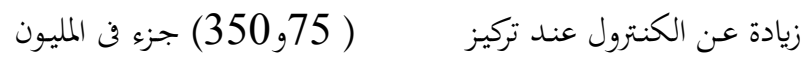

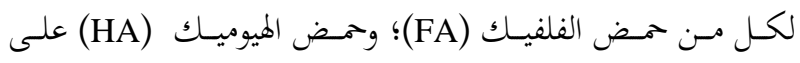
الترتيب. 